\title{
Characterization of Adrenergic Receptors in Membranes from the Rat Seminal Vesicle
}

\author{
Sumio Shima \\ Department of Biochemistry, St. Marianna University School of Medicine, Kawasaki, Kanagawa 213, Japan
}

Received August 5, 1992 Accepted November 10, 1992

\begin{abstract}
Characterization of adrenergic receptors in membranes from the rat seminal vesicle was studied by radioligand binding assay. Seminal vesicle membranes contained saturable and high affinity binding sites for the $\beta$-adrenergic receptor antagonist ${ }^{3} \mathrm{H}$-dihydroalprenolol $\left({ }^{3} \mathrm{H}\right.$-DHA) and for the $\alpha$-adrenergic antagonist ${ }^{3} \mathrm{H}$-prazosin. The observed order of potency for adrenergic agonists in competing for the ${ }^{3} \mathrm{H}$ DHA binding sites: isoproterenol $>$ epinephrine $\simeq$ salbutamol $>$ norepinephrine indicates that these membrane receptors have the properties of $\beta_{2}$-adrenergic receptors. $\alpha_{1}$-Adrenergic receptors were defined mainly as $\alpha_{1 \mathrm{~A}}$ subtypes by demonstrating their insensitivity to pretreatment with chlorethylclonidine and the different rank orders of antagonist affinities. No significant binding sites for the $\alpha_{2}$-adrenergic receptor agonist ${ }^{3} \mathrm{H}$-clonidine were observed. The GTP-induced reduction in the affinity of $\alpha_{1}$-adrenergic receptors for epinephrine was significantly reversed by the muscarinic cholinergic agonist carbachol. Atropine effectively antagonized this effect of carbachol on the competitive inhibition of ${ }^{3} \mathrm{H}$-prazosin binding by epinephrine in the presence of GTP, which suggests that muscarinic cholinergic receptors regulate the affinity of $\alpha_{1}$-adrenergic receptors by modulating the effect of guanine nucleotides. The effect of GTP on decreasing the affinity of $\beta_{2}$-adrenergic receptors was not influenced by the addition of carbachol.
\end{abstract}

Keywords: Adrenergic receptor, Seminal vesicle, Cholinergic regulation

Several reports have suggested the presence of $\alpha$ adrenergic receptors in the rat seminal vesicle $(1,2)$. Adeneken (3) has reported evidence for $\alpha_{1}$-adrenergic receptor predominance in the rat seminal vesicle. A previous study (4) demonstrated that rat seminal vesicle membranes contained $\alpha_{1}$ - and $\beta$-adrenergic receptors regulated inversely by androgens.

In rat ventral prostate membrane preparations, $\beta$ adrenergic agonists stimulated adenylate cyclase activity with the observed properties characteristic of a $\beta_{2}$-subtype receptor (5-7). As for $\alpha_{1}$-adrenergic receptors, it has become increasingly clear that there are at least two pharmacologically distinct subtypes of $\alpha_{1}$-adrenergic receptors: $\alpha_{1 \mathrm{~A}}$-subtypes that are not inactivated by the site-directed alkylating agent chlorethylclonidine (CEC) and $\alpha_{1 \mathrm{~B}}$-subpopulations that are sensitive to CEC $(8-11)$. In the present study, I investigated the properties of $\alpha$ and $\beta$-adrenergic receptors of rat seminal vesicle membranes and the regulation of adrenergic receptors by guanine nucleotides and muscarinic cholinergic agonists.

\section{MATERIALS AND METHODS}

Seminal vesicles from male Wistar rats weighing 300 to $350 \mathrm{~g}$ (Nippon Rats Co., Ltd.) were homogenized in

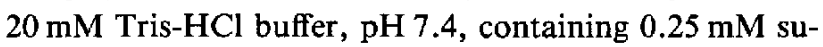
crose, $4 \mathrm{mM} \mathrm{MgCl}, 1 \mathrm{mM}$ EDTA and $3.25 \mathrm{mM} \mathrm{2-mer-}$ captoethanol by a Potter-Elvehjen homogenizer. The homogenate was centrifuged at $600 \times g$ for $10 \mathrm{~min}$. The supernatant was centrifuged at $20,000 \times g$ for $20 \mathrm{~min}$. Crude membrane preparations were incubated for $20 \mathrm{~min}$ with or without $100 \mu \mathrm{M} \mathrm{CEC}$ and washed three times. The membrane preparations were assayed for $\beta$-adrenergic receptor binding with ${ }^{3} \mathrm{H}$-dihydroalprenolol $\left({ }^{3} \mathrm{H}\right.$-DHA, $52.3 \mathrm{Ci} / \mathrm{mmol}$; New England Nuclear, Boston, MA, USA), as previously described $(12-15)$. Membranes $\left(0.2-0.3 \mathrm{mg}\right.$ of protein) were incubated with ${ }^{3} \mathrm{H}-\mathrm{DHA}$ $(1-20 \mathrm{nM})$ in a buffer $(40 \mathrm{mM}$ Tris- $\mathrm{HCl}, \mathrm{pH} 7.4,10 \mathrm{mM}$ $\mathrm{MgCl}_{2}$ ) for $10 \mathrm{~min}$ at $37^{\circ} \mathrm{C}$. The $\alpha_{1}$ - and $\alpha_{2}$-adrenergic receptor binding study was performed with ${ }^{3} \mathrm{H}$-prazosin $(0.1-5.0 \mathrm{nM}, 30 \mathrm{Ci} / \mathrm{mmol}$, New England Nuclear, Boston, MA, USA) or ${ }^{3} \mathrm{H}$-clonidine $(0.5-5.0 \mathrm{nM}$, 
$28.3 \mathrm{Ci} / \mathrm{mmol}$, New England Nuclear, Boston, MA, USA), respectively. Incubations of the membranes (0.1-0.2 mg of protein) with ${ }^{3} \mathrm{H}$-prazosin or ${ }^{3} \mathrm{H}$-clonidine in $40 \mathrm{mM}$ Tris- $\mathrm{HCl}$ buffer, $\mathrm{pH} 7.4$, containing $10 \mathrm{mM}$ $\mathrm{MgCl}_{2}, 1 \mathrm{mM}$ sodium $l$-ascorbate and $1 \mathrm{mM}$ pyrocatechol were carried out for $30 \mathrm{~min}$ at $37^{\circ} \mathrm{C}$, as previously described $(4,16,17)$. For the experiments of CEC pretreatment, incubations of the membranes with or without $100 \mu \mathrm{M} \mathrm{CEC}$ for $20 \mathrm{~min}$ were followed by washing with the medium, 3 times, before the binding assay. Incubations for the binding assay were terminated by a rapid dilution of the assay mixture, followed by filtration through Whatman GF/B glass fiber filters. Specific binding to receptors, defined as the difference between the radioactivity bound in the presence or absence of $20 \mu \mathrm{M}$ propranolol, $10 \mu \mathrm{M}$ phentolamine or $5 \mu \mathrm{M}$ clonidine, was approximately 65 to $75 \%$ of the total binding. The concentrations of protein were measured by the method of Lowry et al. (18).

The drugs used were: $l$-propranolol (Japan ICI Pharma), phentolamine (Japan Ciba Geigy), $l$-isoproterenol (Nikken Chemicals), salbutamol (Sankyo Pharmaceutical), l-epinephrine (Dainippon Seiyaku), norepinephrine (Wako Chemicals), carbachol (Sigma Chemical), chlorethylclonidine (CEC, Research Biochemicals), atropine (Sigma Chemical Co.), 2-2,6-dimethoxy-phenoxyethylaminomethyl-1,4-benzodioxane (WB4101, Amersham) and dihydroergocryptine (DHE, Sandoz).

\section{RESULTS}

The saturable and specific binding of ${ }^{3} \mathrm{H}$-DHA to seminal vesicle membranes was demonstrated by the linearity of the Scatchard analysis, indicating a single class of receptors, and the number of binding sites was calculated to be $93.8 \pm 1.8 \mathrm{fmol} / \mathrm{mg}$ protein with an apparent affinity, $K_{d}$, of $6.3 \pm 0.3 \mathrm{nM}$ (Fig. 1). The agonists competed for the receptor binding sites in the following order of potency: $\quad l$-isoproterenol $>$ epinephrine $>$ salbutamol $>l$ norepinephrine; graphical estimation of the concentration resulting in half maximal inhibition gave $\mathrm{IC}_{50}$ values for isoproterenol, epinephrine, salbutamol and norepinephrine of $0.01,0.61,0.82$, and $2.10 \mu \mathrm{M}$, respectively (Fig. 2). Affinity of the $\beta$-adrenergic receptor for isoproterenol was decreased by the guanine nucleotide (GTP, $50 \mu \mathrm{M}$ ), as demonstrated by an increase of more than one order of magnitude in the $\mathrm{IC}_{50}$ value for isoproterenol in the presence of GTP (Fig. 3). Addition of the cholinergic agonist carbachol $(10 \mu \mathrm{M})$ had no effect on the decreased affinity of the $\beta$-adrenergic receptor for isoproterenol by the guanine nucleotide (Fig. 3).

The binding of ${ }^{3} \mathrm{H}$-prazosin, $\alpha_{1}$-adrenergic antagonist, to seminal vesicle membranes was also to a single, saturable population of sites, with a linear Scatchard plot, and the number of binding sites was $46.8 \pm 0.3 \mathrm{fmol} / \mathrm{mg}$ protein with a high affinity $K_{d}$ of $0.36 \pm 0.01 \mathrm{nM}$ (Fig. 4). Pretreatments with $100 \mu \mathrm{M}$ CEC for 20 min caused no significant decrease in the density of specific ${ }^{3} \mathrm{H}$-prazosin binding sites in seminal vesicle membranes (Fig. 5).

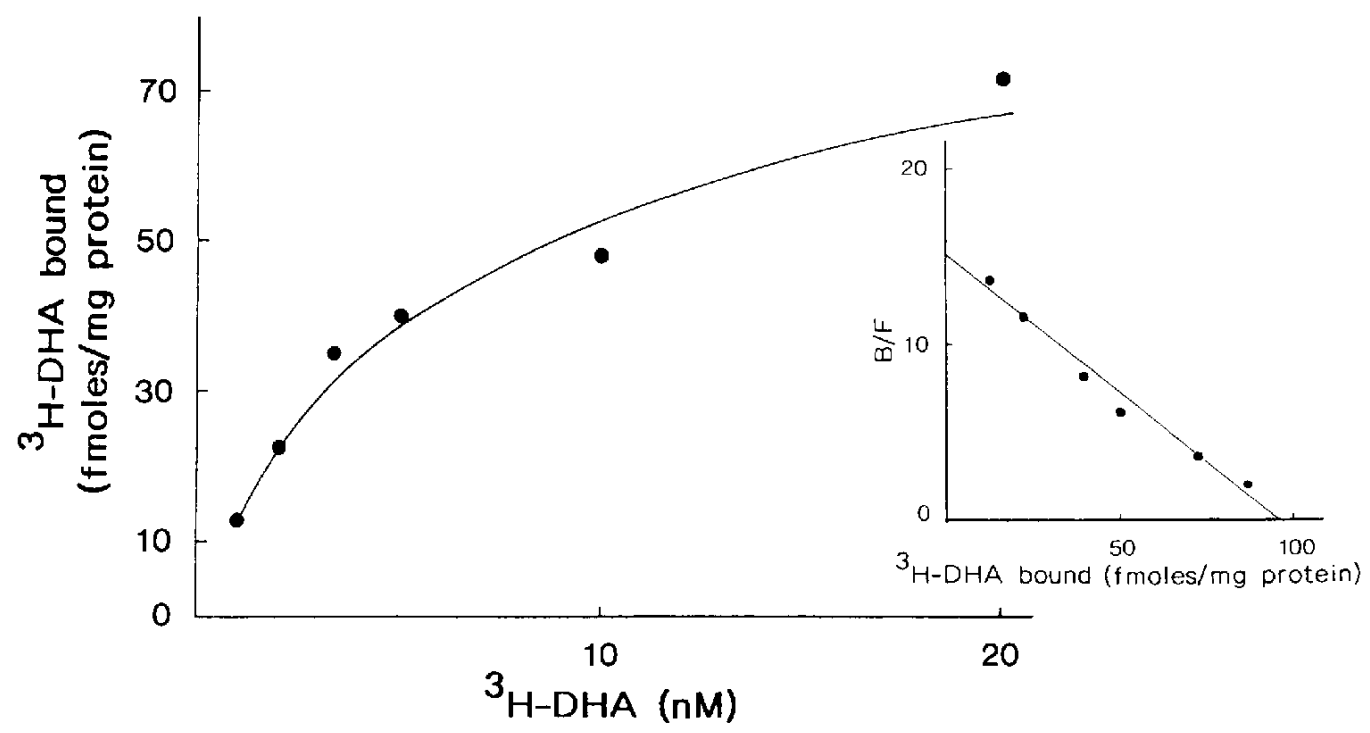

Fig. 1. Representative saturation and Scatchard analysis of ${ }^{3} \mathrm{H}$-dihydroalprenolol $\left({ }^{3} \mathrm{H}-\mathrm{DHA}\right)$ binding to the membrane fraction of the seminal vesicle. Crude membranes were incubated with various concentrations $(1-20 \mathrm{nM})$ of ${ }^{3} \mathrm{H}-\mathrm{DHA}$. Specific binding was determined as described in Materials and Methods. Each value plotted is the mean of four determinations. 


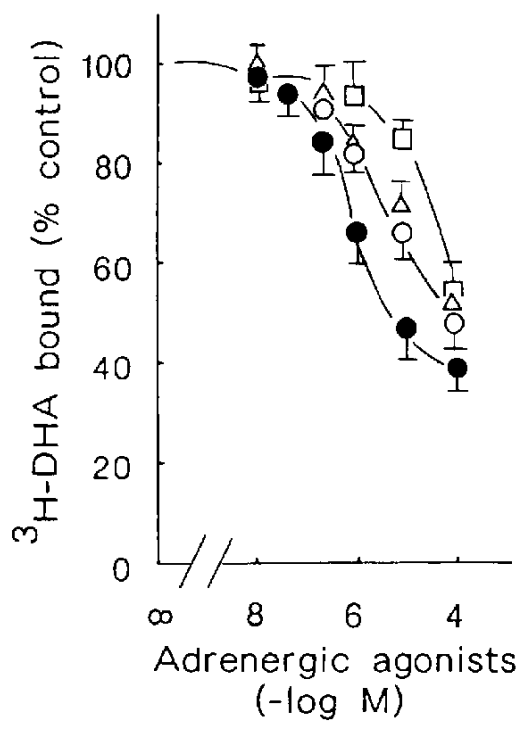

Fig. 2. Displacement curves of ${ }^{3} \mathrm{H}$-dihydroalprenolol $\left({ }^{3} \mathrm{H}-\mathrm{DHA}\right)$ binding to the membrane fraction of the seminal vesicle by various $\beta$-adrenergic agonists. Membranes of the seminal vesicle were incubated with $5 \mathrm{nM}{ }^{3} \mathrm{H}$-DHA and increasing concentrations of the indicated adrenergic agonists $(O$ isoproterenol, $\bigcirc$ epinephrine, $\triangle$ salbutamol, $\square$ norepinephrine) for $10 \mathrm{~min}$. Results are expressed as a percent of the amount bound in the absence of catecholamines. Each value is the mean of four determinations.

Figure 6 shows the competition curves for the antagonists with a rank order of affinity of WB4101>phentolamine $>$ DHE.

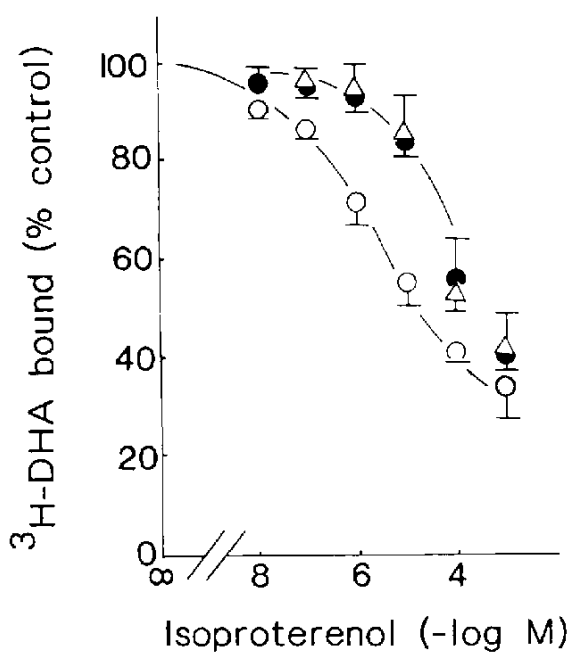

Fig. 3. Isoproterenol competition for ${ }^{3} \mathrm{H}$-dihydroalprenolol $\left({ }^{3} \mathrm{H}\right.$ DHA) binding sites. Membranes of the seminal vesicle were incubated with $5 \mathrm{nM}{ }^{3} \mathrm{H}$-DHA in the presence of the indicated concentrations of isoproterenol with (O) or without (O) $50 \mu \mathrm{M} \mathrm{GTP}$ and in the presence of $10 \mu \mathrm{M}$ carbachol $(\triangle$ ) for $10 \mathrm{~min}$. Maximum specific binding to membranes in the absence of isoproterenol was taken as $100 \%$. Values shown represent the means of four determinations.

Guanine nucleotide (GTP, $100 \mu \mathrm{M}$ ) significantly decreased the affinity of $\alpha_{1}$-adrenergic receptors for epinephrine, causing an increase of more than one order of magnitude in the $\mathrm{IC}_{50}$ value for epinephrine in the presence of GTP (Fig. 7). The GTP-induced reduction in the affinity of $\alpha_{1}$-adrenergic receptors for epinephrine was
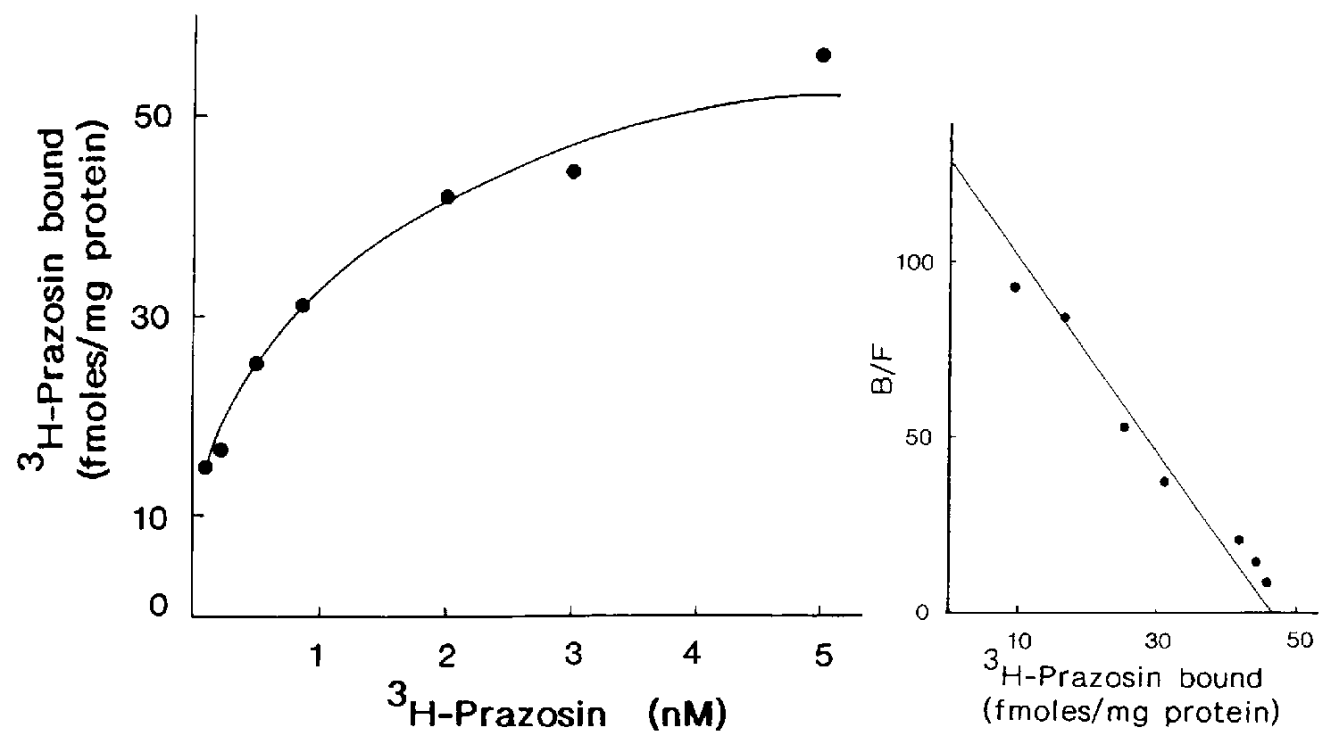

Fig. 4. Representative saturation and Scatchard analysis of ${ }^{3} \mathrm{H}$-prazosin binding to the membrane fractions of the seminal vesicle. Crude membranes were incubated with various concentrations $(0.1-5 \mathrm{nM})$ of ${ }^{3} \mathrm{H}$-prazosin. Specific binding was determined as described in Materials and Methods. Each value plotted is the mean of four determinations. 


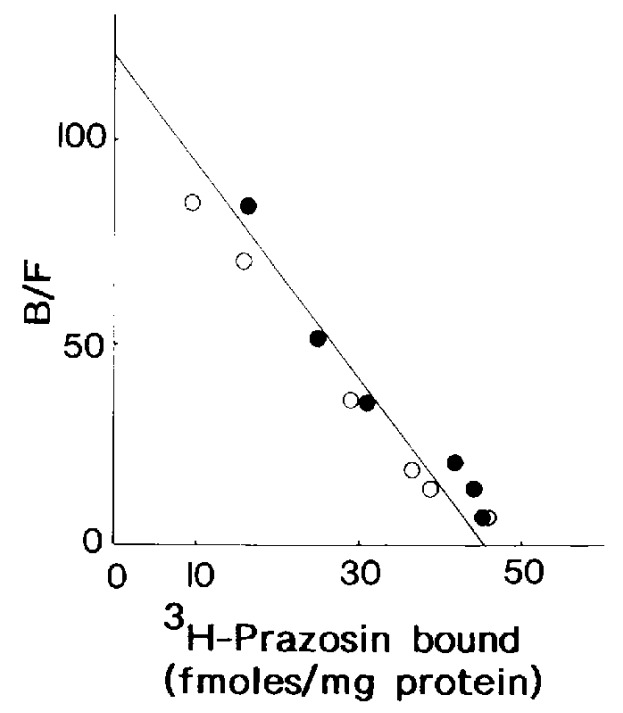

Fig. 5. Effects of chlorethylclonidine (CEC) pretreatment on ${ }^{3} \mathrm{H}$ prazosin binding sites in membranes of the seminal vesicle. Membrane preparations were incubated for $20 \mathrm{~min}$ with (O) or without (O) $100 \mu \mathrm{M} \mathrm{CEC}$ and washed three times. ${ }^{3} \mathrm{H}$-Prazosin binding was determined as described in Materials and Methods. Each value is the mean of four determinations.

significantly reversed by addition of carbachol $(10 \mu \mathrm{M})$ (Fig. 7). Carbachol had no effect on the specific ${ }^{3} \mathrm{H}$-prazosin binding either alone or in the presence of GTP (data

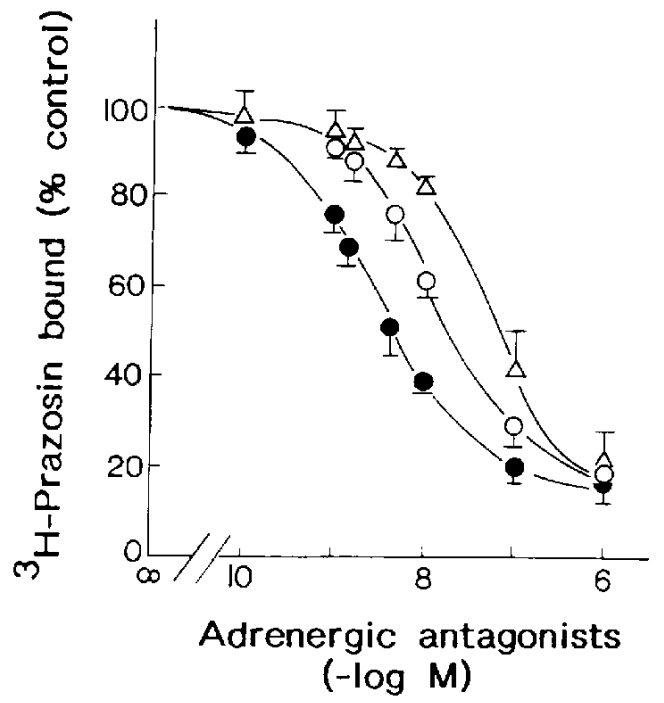

Fig. 6. Displacement curves of the binding of ${ }^{3} \mathrm{H}$-prazosin to the membrane fraction of the seminal vesicle by various $\alpha$-adrenergic antagonists. Membranes of the seminal vesicle were incubated with I nM ${ }^{3} \mathrm{H}$-prazosin and increasing concentrations of the indicated $\alpha$ adrenergic antagonists (OWB4101, $\bigcirc$ phentolamine, $\triangle$ dihydroergocriptine) for $10 \mathrm{~min}$. Results are expressed as a percent of the amount bound in the absence of antagonists. Each value is the mean of four determinations.

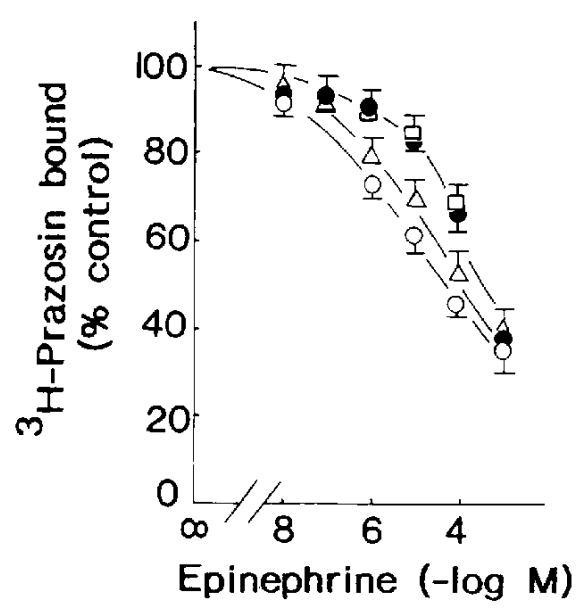

Fig. 7. Epinephrine competition for ${ }^{3} \mathrm{H}$-prazosin binding sites. Membranes of the seminal vesicle were incubated with $1 \mathrm{nM}{ }^{3} \mathrm{H}$ prazosin in the presence of the indicated concentrations of epinephrine with (O) or without ( $50 \mu \mathrm{M}$ GTP and in the presence or absence of $(\triangle) 10 \mu \mathrm{M}$ carbachol and $(\square) 0.1 \mu \mathrm{M}$ atropine for $10 \mathrm{~min}$. Maximum specific binding to membranes in the absence of epinephrine was taken as $100 \%$. Values shown represent the means of four determinations.

not shown). Atropine, an antagonist for muscarinic cholinergic agonists, effectively reversed the effects of carbachol on the competitive inhibition of ${ }^{3} \mathrm{H}$-prazosin binding by epinephrine in the presence of GTP (Fig. 7). No significant binding sites for ${ }^{3} \mathrm{H}$-clonidine were observed (data not shown).

\section{DISCUSSION}

The observed order of potency for agonist in competing for the $\beta$-adrenergic binding sites was $l$-isoproterenol $>$ epinephrine $\simeq$ salbutamol $>l$-norepinephrine, indicating that these receptors have properties characteristic of a typical $\beta_{2}$-adrenergic receptor system. Guanine nucleotides have been reported to modulate receptor binding function (19-22). Membranes from seminal vesicles responded to GTP with decreased $\beta$-adrenergic receptorligand affinity. Carbachol, a muscarinic cholinergic agonist, had no effect on the GTP regulation. Membranes from the rat seminal vesicle showed saturable and high affinity binding sites for the $\alpha_{1}$-adrenergic receptor antagonist, confirming the previous study (4). No specific binding for the $\alpha_{2}$-adrenergic receptor agonist ${ }^{3} \mathrm{H}$-clonidine was observed (data not shown), indicating a predominance of $\alpha_{1}$-adrenergic receptors in the rat seminal vesicle (3). Guanine nucleotides have been demonstrated to decrease the affinity of $\alpha_{1}$ - and $\alpha_{2}$-adrenergic receptors for epinephrine $(23,24)$. The effect of GTP on decreasing the affinity of the $\alpha_{1}$-adrenergic receptor bind- 
ing was apparent in rat seminal vesicle membranes. The effect of GTP reducing the affinity of $\alpha_{1}$-adrenergic receptors for epinephrine was reversed by addition of carbachol, and atropine, a muscarinic cholinergic receptor antagonist, effectively antagonized this effect of carbacol on the competitive inhibition of ${ }^{3} \mathrm{H}$-prazosin by epinephrine in the presence of GTP, suggesting a mediation by muscarinic cholinergic receptors in the regulatory components of guanine nucleotides for $\alpha_{1}$-adrenergic receptors. The presence of muscarinic cholinergic receptor in the rat seminal vesicle has been suggested by the contractile response of the organ to muscarinic cholinergic agonists (25).

Yamada et al. (26) have reported a muscarinic cholinergic agonist regulating the affinity of cardiac $\alpha_{1}$-adrenergic receptors by modulating the effect of guanine nucleotides.

Recently, the irreversible alkylating agent, CEC, a reactive derivative of clonidine has been reported to inactivate only a subpopulation of $\alpha_{1}$-adrenergic receptor binding sites with the characteristics of the CEC-sensitive subtype $\left(\alpha_{1 \mathrm{~B}}\right)(8-10)$. The distribution of $\alpha_{1}$-adrenergic receptors of the CEC-insensitive $\alpha_{1 \mathrm{~A}^{-}}$-subtype and CEC-sensitive $\alpha_{1 \mathrm{~B}^{-}}$ subtype has been reported in various tissues such as hepatocytes $(9,11,27-29)$, renal cells (11), thyroid cells $(30,31)$ brain $(8,9,28,32)$, aorta $(27,29)$, spleen and vas deferens (9). More recently, Lomansney et al. (33) have stated that the $\alpha_{1 \mathrm{~A}}$-subtype in COS-7 cell membranes appears to be less sensitive to inactivation by CEC $(\sim 15 \%)$ than the $\alpha_{1 \mathrm{~B}}(70 \%)$ and $\alpha_{1 \mathrm{C}}(80 \%)$ subtypes. Pretreatment of membranes with $10 \mu \mathrm{M} \mathrm{CEC} \mathrm{had} \mathrm{no} \mathrm{effect} \mathrm{on}{ }^{3} \mathrm{H}$-prazosin binding, suggesting that $\alpha_{1}$-adrenergic receptors of rat seminal vesicles are mostly of the $\alpha_{1 \mathrm{~A}}$-subtype. Moreover, the types of ${ }^{3} \mathrm{H}$-prazosin binding in this assay exhibited the pharmacological profile of antagonists, WB4101> phentolamine $>$ DHE, which were against the $\alpha_{1 \mathrm{~A}}$-subtype of adrenergic receptor (32).

\section{REFERENCES}

1 Castelli, M. and Genedani, S.: Phentolamine inhibition of rat seminal vasicle response to dopaminemimetic drugs: $\alpha$ adrenoceptor implication or lack of specificity? J. Pharm. Pharmacol. 34, 331 - 333 (1982)

2 Hib, J., Ponzio, R. and Vilar, O.: Effects of autonomic drugs on contractions of rat seminal vesicles in vivo. $J$. Reprod. Fert. 70, $197-202$ (1984)

3 Adenekan, O.: Evidence for $\alpha_{1}$-adrenoceptor subtype predominance in the rat seminal vesicle. J. Pharm. Pharmacol. 41, $277-278$ (1989)

4 Fukase, $\mathbf{H}$.: Inverse regulation of $\alpha_{1}$ - and $\beta$-adrenergic receptors by androgen in the membrane of rat seminal vesicle. St. Marianna Med. J. 18, $422-428$ (1990)

5 Shima, S., Kawashima, Y., Hirai, M. and Asakura, M.: Effect of adrenergic stimulation on adenylate cyclase activity in rat prostate. Biochim. Biophys. Acta 628, 255-262 (1980)
6 Poyet, P., Gagne, B., Lavoie, M. and Labrie, F.: Characteristics of the $\beta$-adrenergic receptor in the rat ventral prostate using ${ }^{125}$ I-cyanopindolol. Mol. Cell. Endocrinol. 48, 59-67 (1986)

7 Poyet, P., Gagne, B. and Labrie, F.: Characteristics of the $\beta$-adrenergic stimulation of adenylate cyclase activity in rat ventral prostate and its modulation by androgens. Prostate 9 , $237-245$ (1986)

8 Johnson, R.D. and Minneman, K.P.: Differentiation of $\alpha_{1}$ adrenergic receptors linked to phosphatidyl inositol turnover and cyclic AMP accumulation in rat brain. Mol. Pharmacol. 31, 239-246 (1987)

9 Han, C., Abel, P.W. and Minneman, K.P.: Heterogeneity of $\alpha_{1}$-adrenergic receptors revealed by chlorethylclonidine. Mol. Pharmacol. 32, 505-510 (1987)

10 Minneman, K.D., Han, C. and Abel, P.W.: Comparison of $\alpha_{1}$ adrenergic receptor subtypes distinguished by chlorethylclonidine and WB 4101. Mol. Pharmacol. 33, 509-514 (1988)

11 Han, C., Wilson, K.M. and Minneman, K.P.: $\alpha_{1}$-Adrenergic receptor subtypes and formation of inositol phosphates in dispersed hepatocytes and renal cells. Mol. Pharmacol. 37, 903-910 (1990)

12 Shima, S., Hirai, M. and Asakura, M.: Regulation of the adenylate cyclase system by catecholamines in the rat prostate. Naunyn Schmiedebergs Arch. Pharmacol. 312, 19-22 (1980)

13 Shima, S., Kawashima, Y., Hirai, M. and Asakura, M.: Effects of androgens in isoproterenol-sensitive adenylate cyclase system of the rat prostate. Mol. Pharmacol. 18, 45-48 (1980)

14 Shima, S., Komoriyama, K., Hirai, M. and Kouyama, H.: Blockade of heterologous desensitization of prostate adenylate cyclase without blockade of homologous down-regulation of receptors or loss of GTP regulation of agonist binding. J. Biol. Chem. 258, 2083-2086 (1983)

15 Shima, S., Akamatu, N., Hirai, M. and Kouyama, H.: Agerelated alterations in the catecholamine-sensitive adenylate cyclase system of the prostate. Mol. Pharmacol. 27, 218-222 (1985)

16 Shima, S., Fukase, H. and Akamatu, N.: Desensitization of $\alpha$ adrenergic glycogenolytic response in rat hepatocytes. Asia Pacific J. Pharmacol. 5, 27-32 (1990)

17 U'Prichard, D.C., Greenberg, D.A. and Snyder, S.H.: Binding characteristics of a radioligand agonist and antagonist at central nervous system alpha-noradrenergic receptors. Mol. Pharmacol. 13, 454-462 (1977)

18 Lowry, O.H., Rosebrough, N.J., Farr, A.J. and Randall, R.J.: Protein measurement with the Folin phenol reagent. J. Biol. Chem. 193, 265-275 (1951)

19 Rodbell, M., Krams, H.J., Pohl, S.L. and Birnbaumer, L.: The glucagon-sensitive adenylate cyclase system in plasma membranes of rat liver. J. Biol. Chem. 246, 1872-1876 (1971)

20 Lin, M.C., Nicosia, S., Lad, P.M. and Rodbell, M.: Effects of GTP on binding of ${ }^{3} \mathrm{H}$-glucagon to receptors in rat hepatic plasma membranes. J. Biol. Chem. 252, 2790-2792 (1977)

21 Lefkowitz, R.J., Mullikin, D. and Caron, M.G.: Regulation of $\beta$-adrenergic receptor by guanyl-5'-yl-imidodiphosphate and other nucleotides. J. Biol. Chem. 251, 4686-4692 (1976)

22 Lefkowitz, R.J. and Williams, L.T.: Catecholamine binding to the $\beta$-adrenergic receptor. Proc. Natl. Acad. Sci. U.S.A. 74, $515-519$ (1977)

23 Snavly, M.D. and Insel, P.A.: Characterization of alphaadrenergic receptor subtypes in the rat renal cortex. Differential 
regulation of alpha ${ }_{1}$ - and alpha $a_{2}$-adrenergic receptors by guanyl nucleotides and $\mathrm{Na}$. Mol. Pharmacol. 22, 532-546 (1982)

24 Terman, B.I., Slivka, S.R., Hughes, R.J. and Insel, P.A.: $\alpha_{1}$ Adrenergic receptor-linked guanine nucleotide-binding protein in muscle and kidney epithelial cells. Mol. Pharmacol. 31, 12-20 (1987)

25 Picarelli, Z.P. and Valle, J.R.: Hormonal regulation of rat seminal vesicle sensitivity to adrenaline, noradrenaline and acetyl- $\beta$ methylcholine. Br. J. Pharmacol. 35, 468-475 (1969)

26 Yamada, S., Yamamura, H.I. and Roeske, W.R.: The regulation of cardiac $\alpha_{1}$-adrenergic receptors by guanine nucleotides and by muscarinic cholinergic agonists. Eur. J. Pharmacol. 63, 239-241 (1980)

27 Tsujimoto, G., Tsujimoto, A., Suzuki, E. and Hashimoto, K.: Glycogen phosphorylase activation by two different $\alpha_{t}$-adrenergic receptor subtypes: methoxamine selectively stimulates a putative $\alpha_{1}$-adrenergic receptor subtype ( $\left.\alpha_{1 \mathrm{~A}}\right)$ that couples with $\mathrm{Ca}^{2+}$ influx. Mol. Pharmacol. 36, 166-176 (1989)

28 Terman, B.I., Riek, R.P., Grodski, A., Hess, H.J. and Graham, R.M.: Identification and structural characterization of $\alpha_{1}$-adrenergic receptor subtypes. Mol. Pharmacol. 37, 526- 534 (1990)

29 Torres-Manquez, M.E., Villalobos-Molina, R. and GarciaSainz, J.A.: $\alpha_{1}$-Adrenoceptor subtypes in aorta $\left(\alpha_{1 \mathrm{~A}}\right)$ and liver $\left(\alpha_{1 \mathrm{~B}}\right)$. Eur. J. Pharmacol. 206, 199-202 (1991)

30 Shimura, H., Endo, T., Tsujimoto, G., Watanabe, K., Hashimoto, K. and Onaya, T.: Characterization of $\alpha_{1}$-adrenergic receptor subtypes linked to iodide effiux in FRTL cells. J. Endocrinol. 124, 433-441 (1990)

31 Shimura, H., Endo, T. and Onaya, T.: Thyrotropin increases the $\alpha_{1 \mathrm{~B}}$-adrenergic receptors in rat thyroid gland in vivo. J. Endocrinol. 126, 317-322 (1990)

32 Morrow, A.L. and Creese, I.: Characterization of $\alpha_{1}$-adrenergic receptor subtypes in rat brain: A reevaluation of ${ }^{3} \mathrm{H}$-WB4104 and ${ }^{3} \mathrm{H}$-prazosin binding. Mol. Pharmacol. 29, $321-330$ (1986)

33 Lomasney, J.W., Cotecchia, S., Lefkowitz, R.J. and Caron, M.G.: Molecular biology of $\alpha$-adrenergic receptors: Implications for receptor classification and for structure-function relationships. Biochim. Biophys. Acta 1095, 127-139 (1991) 